\title{
Correction to: Ptotic Right Retro-renal Liver Lobe Injury During Supine Percutaneous Nephrolithotomy Managed by Hemostatic Sponge
}

\author{
İbrahim Üntan $^{1} \mathbb{D} \cdot$ Volkan Sabur ${ }^{2}$
}

Published online: 9 November 2021

(c) The Author(s) 2021

\author{
Correction to: Indian Journal of Surgery \\ https://doi.org/10.1007/s12262-021-03035-2
}

The article "Ptotic Right Retro-renal Liver Lobe Injury During Supine Percutaneous Nephrolithotomy Managed by Hemostatic Sponge", written by İbrahim Üntan and Volkan Sabur, was originally published electronically on the publisher's internet portal on 20 July 2021 without open access. With the author(s)' decision to opt for Open Choice the copyright of the article changed on 06 October 2021 to $\odot$ The Author(s) 2021 and the article is forthwith distributed under the terms of the Creative Commons Attribution 4.0 International License, which permits use, sharing, adaptation, distribution and reproduction in any medium or format, as long as you give appropriate credit to the original author(s) and the source, provide a link to the Creative Commons licence, and indicate if changes were made. The images or other third party material in this article are included in the article's Creative Commons licence, unless indicated otherwise in a credit line to the material. If material is not included in the article's Creative Commons licence and your intended use is not permitted by statutory regulation or exceeds the permitted use, you will need to obtain permission directly from the copyright holder. To view a copy of this licence, visit http://creativecommons.org/licenses/by/4.0/.

The original article has been corrected.

Open Access This article is licensed under a Creative Commons Attribution 4.0 International License, which permits use, sharing, adaptation, distribution and reproduction in any medium or format, as long as you give appropriate credit to the original author(s) and the source, provide a link to the Creative Commons licence, and indicate if changes were made. The images or other third party material in this article are included in the article's Creative Commons licence, unless indicated otherwise in a credit line to the material. If material is not included in the article's Creative Commons licence and your intended use is not permitted by statutory regulation or exceeds the permitted use, you will need to obtain permission directly from the copyright holder. To view a copy of this licence, visit http://creativecommons.org/licenses/by/4.0/.

Publisher's Note Springer Nature remains neutral with regard to jurisdictional claims in published maps and institutional affiliations.

The original article can be found online at https://doi.org/10.1007/ s12262-021-03035-2.

İbrahim Üntan

ibrahimuntan@erciyes.edu.tr

Volkan Sabur

volkansabur@gmail.com

1 Department of Urology, Ahi Evran University, Training and Research Hospital, Kervansaray Mah. 2019. Sok., 40100 Kirsehir, Turkey

2 Department of Urology, Erciyes Kartal Hospital, Kayseri, Turkey 